\title{
MONITORING THE VIABILITY OF CITRUS ROOTSTOCKS SEEDS STORED UNDER REFRIGERATION ${ }^{1}$
}

\author{
SÉRGIO ALVES DE CARVALHO² \& LUIS FERNANDO CARVALHO SILVA ${ }^{3}$
}

\begin{abstract}
The citrus nursery tree is produced through the bud grafting process, in which rootstock is usually grown from seed germination. The objective of this research was to evaluate, in two dissimilar environmental conditions, the viability and polyembryony expression of five citrus rootstocks seeds stored in different periods under refrigeration. The rootstock varieties evaluated were: Rangpur lime (Citrus limonia Osb. cv. Limeira), Trifoliate orange (Poncirus trifoliata Raf. cv. Limeira), Citrumelo (P. trifoliata x C. paradisi Macf. cv. Swingle), Sunki mandarin (C. sunki Hort. ex Tanaka) and Volkamer lemon (C. volkameriana Ten. \& Pasq. cv. Catania 2). The experimental design was the randomized blocks in a $11 \times 5 \times 2$ factorial scheme, evaluating from time zero to the tenth month of storage, the five varieties of rootstock in two environments: germination and growth B.O.D type chamber (Biological Oxygen Demand - Eletrolab Brand Model FC 122) at $25^{\circ} \mathrm{C}$; and greenhouse seedbed with partial temperature control $\left(22{ }^{\circ} \mathrm{C}\right.$ to $\left.36{ }^{\circ} \mathrm{C}\right)$ and humidity control (75-85\%). The plot had 24 seeds in four replicates, using trays with substrate in greenhouse and Petri dishes with filter paper in B.O.D. chamber. The seed germination rate and polyembryony expression were evaluated monthly. It was concluded that Trifoliate and Citrumelo Swingle seeds can be stored for up to seven months, while Volkamer lemon, Rangpur lime and Sunki seeds can be stored for up to ten months. The polyembryony expression rate was slightly higher when measured in greenhouse than in B.O.D. chamber and remained stable in both environments until the seventh month, from which dropped sharply. Citrumelo Swingle seeds expressed the highest polyembryony rate (18.8\%), followed by Rangpur lime and Volkamer lemon (average value of 13.7\%), Sunki (9.4\%) and Trifoliate (3.2\%). Despite some differences among varieties, the viability of rootstock stored seeds can be monitored either in the greenhouse or in B.O.D. germination chamber, the latter being the faster and more suitable method.
\end{abstract}

Index terms: Citrus, propagation, seed storage, germination, polyembryony.

\section{MONITORAMENTO DA VIABILIDADE DE SEMENTES PORTA-ENXERTOS DE CITROS ARMAZENADOS EM CÂMARA FRIA}

RESUMO - A muda cítrica é resultado do processo de enxertia, sendo os porta-enxertos geralmente propagados por meio de sementes. O objetivo desta pesquisa foi caracterizar, em duas condições ambientais, a viabilidade e a expressão da poliembrionia de sementes de porta-enxertos de citros armazenadas durante diferentes períodos sob refrigeração. As variedades porta-enxertos avaliadas foram: limão-Cravo (Citrus limonia Osb. cv. Limeira), Trifoliata (Poncirus trifoliata Raf cv. Limeira), Citrumelo (P. trifoliata x C. paradisi Macf. cv. Swingle), tangerina Sunki (C. sunki Hort. ex Tanaka) e limão Volkameriano (C. volkameriana Ten. \& Pasq. cv. Catania 2). O delineamento experimental foi o de blocos casualisados, em esquema fatorial $11 \mathrm{x}$ $5 \times 2$, em 4 repetições, avaliando-se, do tempo zero ao décimo mês de armazenamento, as cinco variedades e os dois ambientes: câmara de germinação e crescimento tipo B.O.D. ("Biological Oxigen Demand" - a $\left.25^{\circ} \mathrm{C}\right)$ e casa de vegetação $\left(22^{\circ} \mathrm{C}\right.$ to $\left.36^{\circ} \mathrm{C}\right)$. Cada parcela foi composta por 24 sementes, utilizando-se de placas de Petri com papel-filtro na câmara B.O.D e bandejas com substrato na casa de vegetação. Avaliou-se mensalmente a taxa de germinação e expressão da poliembrionia. Concluiu-se que as sementes do Trifoliata e do citrumelo Swingle podem ser armazenadas em câmara fria por até sete meses, e as de limão Volkameriano, de limão Cravo e de tangerina Sunki, por até dez meses. Independentemente da variedade porta-enxerto, a taxa de expressão da poliembrionia foi ligeiramente superior em casa de vegetação, mantendo-se estável nos dois ambientes até o sétimo mês, a partir do qual diminuiu bruscamente. As sementes de Citrumelo expressaram a maior taxa de poliembrionia $(18,8 \%$ ), seguida das dos limões Cravo e Volkameriano (valor médio 13,7\%), tangerina Sunki (9,4\%) e Trifiloata (3,2\%). Apesar de algumas diferenças entre variedades, o monitoramento da viabilidade das sementes armazenadas pode ser feito tanto em casa de vegetação quanto em câmara de germinação tipo B.O.D., sendo o último mais rápido e prático.

Termos para indexação: Citrus, propagação, armazenamento de sementes, germinação, poliembrionia.

\footnotetext{
${ }_{1}^{1}$ (Trabalho 062-12). Recebido em: 10-01-2012. Aceito para publicação em: 07-01-2012.

${ }^{2}$ Eng. Agr. Dr., Pesquisador Científico Centro Avançado de Pesquisas Tecnológicas do Agronegócio de Citros Sylvio Moreira - IAC. Caixa Postal 04 CEP 13490-970 - Cordeirópolis, SP. Email: sergio@centrodecitricultura.br

${ }^{3}$ Biólogo, Assistente Técnico de Pesquisa, CAPTACSM-IAC. Email: 1fernando@centrodecitricultura.br
} 


\section{INTRODUCTION}

Availability and quality of rootstock seeds are quite important factors in citrus nursery trees production. Under Brazilian conditions, the fruit ripening time of most rootstock varieties occurs between the months of April and June, while the production of seedlings is performed throughout the year. Thus, to assure the availability of seeds until the new fruit harvest, nurserymen need to store the seeds, in which, even under refrigerated conditions, results in loss of its germination rate (CARVALHO et al, 2005, DANTAS, 2009).

As to the initial physiological condition, the deterioration rate of stored seeds is influenced by variety, humidity and air temperature, growth of pathogens (KOLLER et al., 1993, MARTINS et al., 2007) and further by chemical treatment, manipulation and type of packaging (NAUER and CARSON, 1985, CARVALHO et al., 2002a). Aspergillus sp. and Penicilliumn sp. fungi stand out among the pathogens, growing easily in the temperature range of $5{ }^{\circ} \mathrm{C}$ to $40^{\circ} \mathrm{C}$, which compromise the seed quality, (MACHADO, 1988). In general, seeds are better stored as the water content is reduced, but recalcitrant seeds such as the Swingle Citrumelo (Poncirus trifoliata $\times$ C. paradisi), need more water content for their conservation and generally have lower longevity, which may affect their quality preservation during storage (CARVALHO, 2001).

In addition to the sexual or zygotic embryo, most citrus seeds also present nucellar embryos, formed by somatic nucellus cells, characterizing the nucellar polyembryony (FROST; SOOST, 1968). Germination capacity of one or more embryos from a seed depends on its initial physiological quality, related to the proper ripening fruits stage, nutritional and health aspects of the plant and seed processing conditions. As the nucellar seedlings have the same genetic characteristics from the mother plant, the production of rootstocks via nucellar embryo is very important for more uniform seedlings formation, being interesting to evaluate the polyembrionic expression rate after periods of seed storage.

Brazilian citrus growers based theirs orchards basically in a single variety of rootstock, the Rangpur lime (Citrus limonia Osb.) that in 2007 was still used in nearly $70 \%$ of the nursery tress in the state of São Paulo (POMPEU JR and BLUMER, 2008). With the recommendation to avoid using Rangpur lime, due to its vulnerability to Citrus Sudden Death, a new citrus disease of unknown etiology that leads to the plant's sudden death, (MACHADO et al., 2004), new studies with rootstocks that have shown to be toler- ant to new diseases, are of a great importance to the citrus industry. One approach in this study is a better understanding of seed behavior under storage as well the improving of methodologies for monitoring the viability of stored seeds to ensure nursery trees production throughout the year.

The objective of this research was to determine, through evaluation in greenhouse, germination and growth chamber conditions, the germination and polyembryony expression of five citrus rootstock seeds, stored for a ten months period in cold chamber.

\section{MATERIALS AND METHODS}

The experiment was conducted at the Centro APTA Citrus "Sylvio Moreira" (CAPTACSM), Instituto Agronômico de Campinas (IAC), located in Cordeirópolis, state of São Paulo, Brazil, during the period of April 2005 to July 2006. The citrus rootstocks varieties evaluated were: Rangpur lime (Citrus limonia Osb. cv. Limeira), Trifoliate orange (Poncirus trifoliata Raf. cv. Limeira), Citrumelo ( $P$. trifoliata x C. paradisi Macf. cv. Swingle), Sunki mandarin (C. sunki Hort. ex Tanaka) and Volkamer lemon (C. volkameriana Ten. \& Pasq.cv. Catania 2).

The experimental design used was the randomized blocks in a factorial scheme $11 \times 5 \mathrm{x}$ 2 , evaluating from time zero to the tenth month of storage, the five varieties of rootstock in two environments: germination and growth B.O.D type chamber (Biological Oxygen Demand - Eletrolab Brand Model FC 122) at $25^{\circ} \mathrm{C}$; and greenhouse seedbed with partial temperature control $\left(22^{\circ} \mathrm{C}\right.$ to $36^{\circ} \mathrm{C}$ ) and humidity control (75-85\%). The plot had 24 seeds in four replicates.

The seeds were mechanically extracted from fruit of CAPTACSM-IAC mother trees rootstock blocks. After washing in water to remove the mucilage, the seeds were dried in the shade under ventilation and treated with commercial fungicides [Captan $(6 \mathrm{~mL})$ and Thyran $(4 \mathrm{~mL})$ diluted in $10 \mathrm{~mL}$ of water per $\mathrm{kg}$ of seeds], packed up in a $1 \mathrm{~kg}$ permeable paper bag, which was then wrapped in a impermeable plastic bag and stored in cold chamber at $5^{\circ} \mathrm{C}$. The seed lots physical condition was visually analyzed monthly, and when necessary, it was dried again to remove moisture excess. Visibly deteriorated or contaminated seeds were removed by manual selection. Then, the seed fungicide treatment was applied once more, re-packed as described before, and put back in cold chamber at $5{ }^{\circ} \mathrm{C}$.

At time zero of storage, seeds were sown soon after the drying and chemical treatment, varying ac- 
cording to each variety fruit ripening time: April for Trifoliate, May for Citrumelo, Sunki and Volkamer lemon, and in June for Rangpur lime. Further sowings were taken each thirty days after time zero.

For germination and growth B.O.D. type chamber test were used $25 \mathrm{~cm}$ diameter Petri plates, lined with filter paper moistened with distilled water until its maximum absorption. The viable seeds were manually separated from non-viable seeds, disinfected for 10 minutes in a "Becker" with $90 \%$ sodium hypochlorite in which was added a drop of liquid detergent for each $100 \mathrm{~mL}$ of solution, stirring every minute. Then the seeds were rinsed in distilled water to remove solution excess, and each plate received 24 seeds, with four replicates. The plates were kept in germination and B.O.D. type growth chamber for two months, being irrigated with distilled water at two days intervals to maintain the necessary moisture for seedlings germination.

In germination tests performed in the greenhouse, the seeds were separated by a pre-selection as performed for a controlled environment and sowed in trays with capacity for 96 tubes of $50 \mathrm{~mL}$, filled with vermiculite and pine bark substrate. Using 24 tubes per plot a seed per tube was sowed and the trays were kept in the greenhouse.

B.O.D. type chamber was assessed weekly for seedling emergence evaluation, eliminating, when necessary, rotten or contaminated seeds. At the end of the two month period a final evaluation was performed, determining the number of seedling and the seed polyembryony. At the greenhouse, due to high variations in the emergence of seeds, the evaluation period reached ninety days, taking thirty extra days compared with a germination chamber, evaluated with the same parameters.

Data on the germination percentage and polyembryony expression were subjected to statistical analysis using Sanest software (ZONTA; MACHADO, 1984) with square root transformation $\sqrt{\mathrm{X}+1}$.

\section{RESULT S AND DISCUSSION}

The variance analysis for the parameter seed germination rate, pointed no influence of any environmental factor, but significant effect was found by storage period and rootstock factors, as well as for all double and triple interactions. Regarding polyembryony, the effects were observed only for the individual factors, with no interactions between them.

Zucareli et al. (2009) evaluated the drying and removal of the seed coat in Swingle Citrumelo germination and concluded that this variety tolerates a high degree of desiccation. Meanwhile, according to Khan et al. (2003), the seed viability, as measured by germination, was reduced for Sacaton citrumelo seeds when the moisture content was dropped below $12 \%$. In agreement with the previous authors and Carvalho (2001), those consider the varieties Trifoliata and Swingle citrumelo as high recalcitrant seeds, with reduced longevity and requiring higher water content for its conservation, the data obtained in our study indicates lower germination rates for these varieties in relation to Volkamer lemon, Rangpur lime and Sunki mandarin. When germinated in a greenhouse, the Trifoliate and Citrumelo seed germination rates were close to $55 \%$ and $75 \%$, respectively. For both rootstocks, the B.O.D. average values were still $5 \%$ lower than in the greenhouse (Table 1).

Volkamer lemon and the Rangpur lime presented a higher seed germination rate in B.O.D., reaching over $90 \%$, values averaged to $8 \%$ higher than in greenhouse conditions. Otherwise, there was no environment effect for Sunki mandarin; therefore germination average rates were close to $100 \%$ in both, greenhouse and B.O.D. (Table 1).

From the first to the seventh month of storage, Trifoliate seeds maintained a germination rate around $80 \%$ in both environment, but almost no viable seed remained in the eighth month, when the rate dropped to $7.5 \%$ (Table 1). On the other hand, Citrumelo seeds germination average rate was only $57 \%$ in the first month, increasing to $90 \%$ from the second to the seventh month. This improved germination rate observed after storage of Citrumelo seeds corroborates to those obtained by Carvalho et al. (2002) for the same rootstock, suggesting that the maintenance in cold condition provides seed dormancy breaking. According to these authors, dormancy overcoming may be due to stratification, a process in which the promoter-inhibitor balance is altered by seeds exposure to low temperatures. Trifoliate orange seed dormancy is reported by Koller et al. (1993) and increased seed germination after storage of its rootstock and hybrid seeds is also described by Struiving et al. (2008). By not showing dormancy, the data in our research does not confirm this effect in the Trifoliate seeds.

P. trifoliata and its hybrids are reported in the literature as the citrus rootstock of higher difficulty in storing seeds. Results obtained by Oliveira et al. (2003) and Dantas (2009) show a decrease to less than $10 \%$ in seed germination to the sixth and seventh months of storage for the Trifoliate and Swingle citrumelo. A more drastic reduction on the last rootstock seed germination rate after storage is 
described by Siqueira et al. (2002), dropping to less than $3 \%$ in sixty days. In the present study, a most remarkable reduction occurred only after the eighth month, being possible to obtain an average germination ratio of about $90 \%$ for the Citrumelo and still over $80 \%$ for Trifoliate seeds until the seventh month of storage (Table 1). This result was probably favored by the combined use of the two packages, (permeable paper bag wrapped in impermeable plastic bag) and the moisture monitoring. The waterproof packaging restricts the exchange of moisture, what may be important for maintaining the quality, since dehydration reduces seed germination and seed emergence, as observed for different species of citrus by Saipari et al. (1998), being the Trifoliate the most sensible. On the other hand, there may be an excessive increase in the relative humidity inside the waterproof package, as noted by Carvalho (2001). However, in the present study no water condensation occurred inside the package, since during the monthly assessments of the lots, the paper bags were exchanged when excessive humidity was found. As previously observed by Koller et al. (1993) and Dantas (2009), it could have caused a noticeable deteriorating process, resulting in rotting some seed parts.

Reduction of Rangpur lime seeds germination during the storage period was observed by Dantas (2009), with further reductions from the sixth month, reaching to less than $20 \%$ in the ninth month. In this study, Volkamer lemon and Rangpur lime, as also described by Siqueira et al. (2002), maintained a similar seed germination rate without storage effect when evaluated in a controlled environment (B.O.D.); but in the greenhouse conditions, a decrease in germination rate was observed for Rangpur lime seeds stored for more than eight months (Table 1). Sunki mandarin maintained its seed germination rate between $86 \%$ to $100 \%$ throughout storage and, regardless of the environment, it was the rootstock variety of less variation for this parameter.

As also occurred for seed germination, the Rangpur lime and Volkamer lemon expressed a similar polyembryony rate, around $14 \%$ (Table 2). Nevertheless, these data show, in both environments, an expression far below its varieties' potential, such as the data obtained by counting seed embryos of Prasad and Ravishnkas (1982) and Soares-Filho et al. (1999), which indicated respectively, around 50 and $60 \%$ of polyembryony. For Volkamer lemon, the values were also lower than those observed by Andrade-Rodríguez et al. (2004), who reported $30 \%, 45 \%$ and $55 \%$ of polyembryonic seeds in three consecutive years.

Citrumelo was the rootstock variety with the highest expression of polyembryony, averaging close to $19 \%$, agreeing with the data obtained by Silva and Carvalho (2007). On the other hand, its parental Poncirus trifoliata polyembriony rate was close to 3\% (Table 2), diverging from Frost and Soost (1968), that describe polyembryony rates from $13 \%$ (cross-pollination) to $73 \%$ (selfing-pollination) for this variety. Although, in addition to pollination type, according to the same authors, polyembryony evaluations in citrus can be highly variable even on one tree, due to many factors such as, rootstock, environment and plant age. For Sunki mandarin, there was an expression around $10 \%$, slightly below the $16.8 \%$ polyembryonic seeds observed by Soares Filho et al (2002) for a common clone of this rootstock.

Regarding the storage periods, in addition to any differences among varieties, there was almost no variation in the expression of seed polyembryony until the seventh month (average of 13\%). On the other hand, there was a drastic drop from the eighth month, reaching less than $6 \%$ in the last evaluation (Figure 1). As shown in Figure 2, regardless of rootstock variety, when evaluated in greenhouse the rate of polyembryony expression was slightly higher than in B.O.D. growth chamber. Despite the mechanisms that stimulate the initiation of nucellar embryogenesis in the ovule is not known, it can be assumed that these variations in germination between the environments evaluated, and especially the decrease in polyembryony after prolonged storage of the different varieties studied, are related to influences on the environment within the seeds and consequently in the seed storage proteins, as proposed by Koltunow et al.(1996) for the citrins, as nominated by them the globulin fraction purified from Valencia orange (C. sinensis L. Osb.) seeds. For practical purposes, as getting more uniformity in seedbed is favored by the increased polyembryony expression, the results of our study indicate that in addition to lower germination, the citrus rootstock seed storage for more than seven months, can also cause major problems with the occurrence of plants originating from the zygotic embryo, with loss in its physiological quality compared to each variety standard morphological and agronomic characteristics. 
TABLE 1 - Seed germination rate (\%), assessed in a Biological Oxygen Demand type growth chamber (B.O.D.) and greenhouse, of five citrus rootstock varieties, after different cold storage periods (months).

\begin{tabular}{|c|c|c|c|c|c|c|c|c|c|c|c|c|}
\hline \multirow{3}{*}{ Months } & \multicolumn{12}{|c|}{ Citrus Rootstock } \\
\hline & \multicolumn{3}{|c|}{ Trifoliate Orange } & \multicolumn{3}{|c|}{ Citrumelo } & \multicolumn{2}{|c|}{ Volkamer lemon } & \multicolumn{2}{|c|}{ Rangpur lime } & \multicolumn{2}{|c|}{ Sunki mandarin } \\
\hline & B.O.D. & Greenh & ouse & B.O.D. & Greenho & ouse & B.O.D. & Greenhouse & B.O.D. & Greenhouse & B.O.D. & Greer \\
\hline 0 & $80.97 \mathrm{ab}$ & 70.34 & & $63.49 \mathrm{~cd}$ & 51.97 & & $98.94 \mathrm{a}$ & $75.97 \mathrm{bc}$ & $98.94 \mathrm{a}$ & $94.76 \mathrm{ab}$ & $100.00 \mathrm{a}$ & $95,81 \mathrm{a}$ \\
\hline 1 & $85.37 \mathrm{ab}$ & 86.32 & & $91.61 \mathrm{ab}$ & $86.19 \mathrm{a}$ & & $97.90 \mathrm{a}$ & $82.07 \mathrm{abc}$ & $100.00 \mathrm{a}$ & $92.67 \mathrm{abc}$ & $100.00 \mathrm{a}$ & $97,88 \mathrm{a}$ \\
\hline 2 & $79.77 \mathrm{ab}$ & 90.52 & & $94.78 \mathrm{a}$ & 92.62 & & $98.94 \mathrm{a}$ & $93.69 \mathrm{a}$ & $96.79 \mathrm{a}$ & $95.79 \mathrm{a}$ & $100.00 \mathrm{a}$ & $100,00 \mathrm{a}$ \\
\hline 3 & $73.72 \mathrm{ab}$ & 98.94 & & $97.90 \mathrm{a}$ & 96.86 & & $82.07 \mathrm{a}$ & $92.70 \mathrm{ab}$ & $89.47 \mathrm{a}$ & $73.79 \quad \mathrm{~d}$ & $100.00 \mathrm{a}$ & $100,00 \mathrm{a}$ \\
\hline 4 & $71.72 \mathrm{~b}$ & 86.27 & & $91.49 \mathrm{ab}$ & 91.54 & & $90.56 \mathrm{a}$ & $94.76 \mathrm{a}$ & $96.84 \mathrm{a}$ & $89.47 \mathrm{abcd}$ & $100.00 \mathrm{a}$ & $98,94 \mathrm{a}$ \\
\hline 5 & $84.36 \mathrm{ab}$ & 92.67 & & $76.59 \mathrm{bc}$ & 73.79 & & $97.88 \mathrm{a}$ & $94.71 \mathrm{a}$ & $96.84 \mathrm{a}$ & $91.54 \mathrm{abc}$ & $100.00 \mathrm{a}$ & $100,00 \mathrm{a}$ \\
\hline 6 & $86.27 \mathrm{ab}$ & 95.91 & & $83.30 \mathrm{ab}$ & 94.78 & & $92.67 \mathrm{a}$ & $86.21 \mathrm{abc}$ & $92.70 \mathrm{a}$ & $88.45 \mathrm{abcd}$ & $10000 \mathrm{a}$ & $100,00 \mathrm{a}$ \\
\hline 7 & $89.47 \mathrm{a}$ & 88.48 & & $90.49 \mathrm{ab}$ & $89.52 \mathrm{a}$ & & $94.76 \mathrm{a}$ & $83.25 \mathrm{abc}$ & $94.73 \mathrm{a}$ & $81.10 \mathrm{abcd}$ & $100.00 \mathrm{a}$ & $100,00 \mathrm{a}$ \\
\hline 8 & $9.39 \mathrm{c}$ & 5.93 & $\mathrm{c}$ & $66.05 \mathrm{~cd}$ & 73.83 & $\mathrm{~b}$ & $88.38 \mathrm{a}$ & $84.28 \mathrm{abc}$ & $95.81 \mathrm{a}$ & 77.87 bcd & $100.00 \mathrm{a}$ & $93,64 \mathrm{a}$ \\
\hline 9 & $0.00 \mathrm{~d}$ & 6.09 & $\mathrm{c}$ & $16.32 \mathrm{e}$ & 49.78 & $\mathrm{c}$ & $87.32 \mathrm{a}$ & $89.54 \mathrm{ab}$ & $88.31 \mathrm{a}$ & $76.69 \mathrm{~cd}$ & $98.94 \mathrm{a}$ & $98,94 \mathrm{a}$ \\
\hline 10 & $0.00 \mathrm{~d}$ & 1.67 & $\mathrm{~d}$ & $55.37 \mathrm{~d}$ & 51.81 & $\mathrm{c}$ & $93.64 \mathrm{a}$ & 70.73 & $89.54 \mathrm{a}$ & 72.84 & $97.88 \mathrm{a}$ & $86,07 \mathrm{a}$ \\
\hline Average & $49.05 \mathrm{~B}$ & 55.39 & A & $72.67 \mathrm{~B}$ & 76.43 & & $92.93 \mathrm{~A}$ & $86.00 \mathrm{~B}$ & $94.50 \mathrm{~A}$ & $84.80 \mathrm{~B}$ & $99.71 \mathrm{~A}$ & $97,34 \mathrm{~A}$ \\
\hline
\end{tabular}

Average data followed by distinct lowercase letters in the same column and uppercase letter on the line for the same rootstock, differ by Tukey test at $5 \%$ probability. Coefficient of Variation $(\%)=4,75$.

TABLE 2 - Germination and polyembryony expression rates of five citrus rootstocks seeds. Average data from zero to ten months of cold storage, evaluated in Biological Oxygen Demand type growth chamber (B.O.D.) and greenhouse.

\begin{tabular}{lcc}
\hline Rootstock & Germination rate (\%) & Poliembriony (\%) \\
Trifoliate orange & $52.17 \mathrm{~d}$ & $3.27 \mathrm{~d}$ \\
Swingle citrumelo & $74.54 \mathrm{c}$ & $18.84 \mathrm{a}$ \\
Volkamer lemon & $89.44 \mathrm{~b}$ & $14.21 \mathrm{~b}$ \\
Rangpur lime & $89.58 \mathrm{~b}$ & $13.34 \mathrm{~b}$ \\
Sunki mandarin & $98.52 \mathrm{a}$ & $9.41 \mathrm{c}$ \\
\hline Coeficient of Variation (\%) & 4.75 & 26,09 \\
\hline
\end{tabular}

Average data followed by same letters in columns do not differ by Tukey test at $5 \%$ probability. 


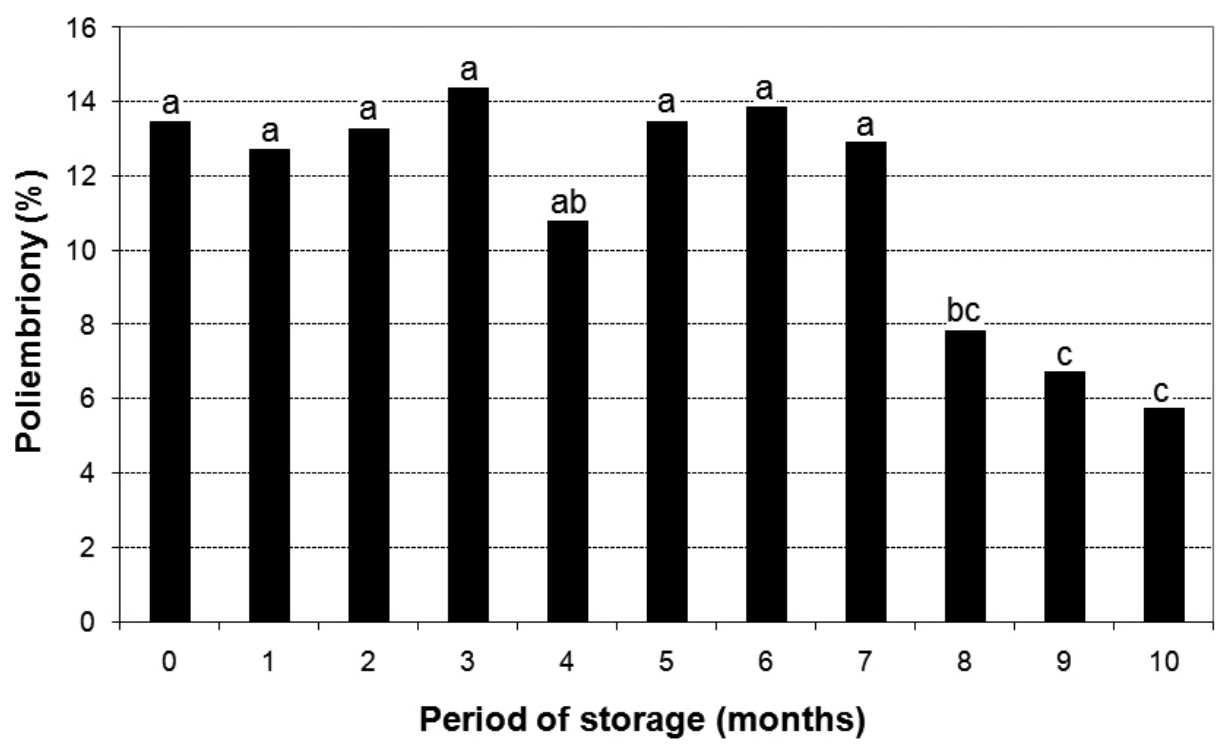

FIGURE 1 -Polyembryony expression after different citrus rootstocks seeds storage periods. Average data of five rootstocks varieties evaluated in two different environments. Columns with same letter do not differ by Tukey test at $5 \%$ probability. Coefficient of variation $=26.9 \%$.

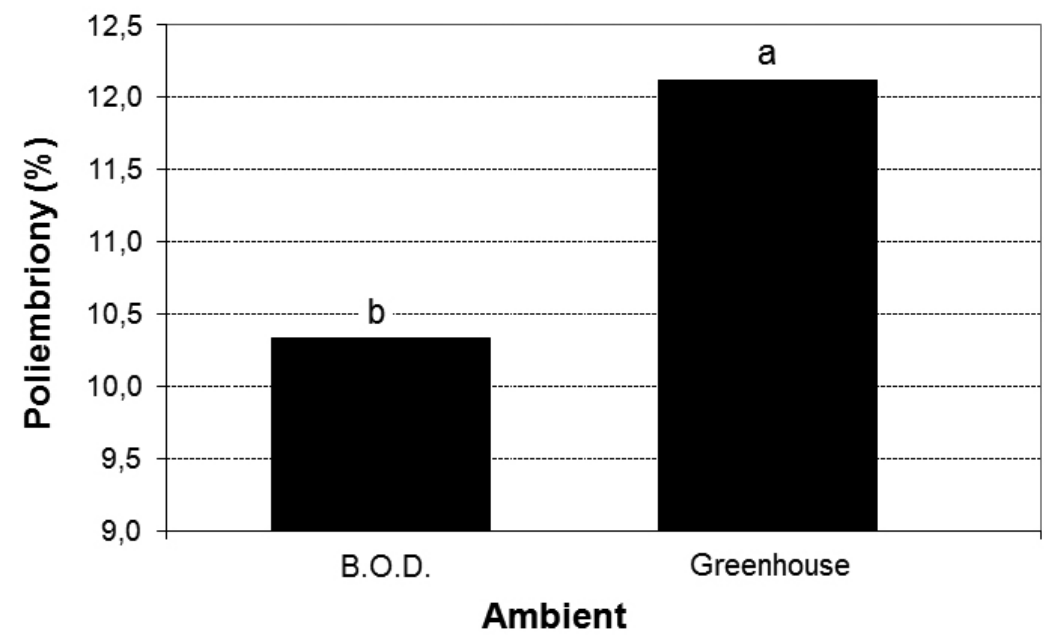

FIGURE 2 - Polyembryony expression of citrus rootstocks seeds, evaluated in Biological Oxygen Demand type chamber (B.O.D.) and greenhouse. Average data from eleven storage periods for five rootstocks varieties. Columns with different letters differ by Tukey test at $5 \%$ probability. Coefficient of variation $=26.9 \%$. 


\section{CONCLUSIONS}

1- For Trifoliate and Citrumelo Swingle rootstocks varieties, cold seed storage is viable for up to seven months, reaching to ten months for Volkamer lemon, Rangpur lime and Sunki mandarin. For Citrumelo, the cold storage for thirty days favored the seed's germination, compared to the non stored ones.

2-The polyembryony rate of different citrus rootstocks seeds was slightly higher when evaluated in greenhouse than in B.O.D. type germination chamber. Regardless the rootstock and environment, it remained stable until the seventh month, from which dropped sharply. Citrumelo expressed the highest polyembryony rate (18.8\%), followed by Rangpur lime and Volkamer lemon (13.7\%), Sunki mandarin $(9.4 \%)$ and Trifiloate orange $(3.2 \%)$.

3-Despite some differences among varieties, the viability of citrus rootstocks stored seeds can be monitored either in greenhouse or in B.O.D. type germination chamber, providing the last environment a faster and suitable test.

\section{REFERENCES}

ANDRADE-RODRÍGUEZ; M.; VILLEGASMONTER, A.; CARRILLO-CASTAÑEDA, G.; GARCIA-VELÁSQUEZ, A. Polyembryony and identification of volkamerian lemon zygotic and nucellar seedlings using RAPD. Pesquisa Agropecuária Brasileira, Brasília, v.39, n. 6, p.551$559,2004$.

CARVALHO, J.A. Conservação de sementes de citros. 2001. 140f. Tese (Doutorado em Agronomia) Escola Superior de Agricultura de Lavras, LAVRAS, 2001.

CARVALHO, J.A.; PINHO, E.V.R.V.; OLIVEIRA, J.A.; GUIMARÃES, R.M.; BONOME, E.T. Qualidade de sementes de Limão-Cravo (Citrus limonia Osbeck) durante o armazenamento. Revista Brasileira de Sementes, Londrina, v. 24, n. 1, p. 286-298, 2002a.

CARVALHO, J.A.; PINHO, E.V.R.V.; OLIVEIRA, J. A.; GUIMARÃES, R. M.; BONOME, L. Testes rápidos para avaliação da qualidade fisiológica de sementes de Citrumelo swingle. Revista Brasileira de Sementes, Londrina, v. 24, n. 1, p. 263-270, 2002.
CARVALHO, S.A.; GRAF, C.C.D.; VIOLANTE, A.R. Produção de material básico e propagação. In: MATTOS JR., D.; DE NEGRI, J. D.; PIO, R.M.; POMPEU JR., J. Citros. Campinas: Instituto Agronômico e Fundag, 2005. cap. 10, p. 279-316.

\section{DANTAS, I.B. Condicionamento fisiológico em} sementes de limão-cravo e citrumelo Swingle. 2009. 123f. Dissertação (Mestrado em Agronomia) - Universidade Federal de Lavras, Lavras, 2009.

FROST, H.B.; SOOST, R.K. Seed reproduction: development of gametes and embryos. In: REUTHER, W.; BATCHELOR, L.D.; WEBBER, H.J. (Ed.). The citrus industry. Berkeley: University of California Press, 1968. v.2, cap.4, p.290-324.

KHAN, M.M.; ALAM, M.A.; ABBAS, M.; IQBAL, M.J. Studies on seed desiccation tolerance in four citrus species. Pakistan Journal of Agricultural Science, Faisalabad, v.40, n.1-2, p.55-672, 2003.

KOLLER, O.L.; STUKER, H.; VERONA, L.F. Efeito da umidade, temperatura de estocagem e duração da estocagem sobre a germinação de Poncirus trifoliata e de outros porta-enxertos de cítrus. Revista Brasileira de Fruticultura, Jaboticabal, v. 15, n. 1, p. 27-33, 1993.

KOLTUNOW, W.A.M.; HIDAKA, T.; ROBINSON, S.P. Polyembryony in Citrus: accumulation of seed storage proteins in seeds and in embryos cultured in vitro. Plant Physiology, Rockville, v.110, n. 2, p.599-609, 1996.

MACHADO, J.C. Patologia de sementes: fundamentos e aplicações. Lavras: ESAL/FAEPE, 1988. $107 \mathrm{p}$

MACHADO, M.A.; TARGON, M.L.P.N.; COLETAFILHO, H.D.; MULLER, G.W. Morte súbita dos citros. Laranja, Cordeirópolis, v.25, n.1, p.69-79, 2004.

MARTINS, L.; SILVA, W.R.; LAGO, A.A. Conservação de sementes de tangerina 'cleópatra': teor de água e temperatura do ambiente. Revista Brasileira de Sementes, Londrina, v.29, n.1, p.178$185,2007$.

NAUER, E.M.; CARSON, T.L. Packaging citrus seed for long-term storage. California Citrograph, Los Angeles, v.70, n.10. p.229-230, 1985. 
OLIVEIRA, R.P.; SCIVITTARO, W.P.; RADMANN, E.B. Procedimentos para o armazenamento de sementes de Poncirus trifoliata (L.) Raf. Revista Brasileira de Fruticultura, Jaboticabal, v.25, n.3, p.461-463, 2003.

POMPEU JÚNIOR, J.; BLUMER, S. Laranjeiras e seus porta-enxertos nos viveiros de mudas cítricas do Estado de São Paulo, em 2004-2007. Laranja, Cordeirópolis, v.29, p.35-50, 2008.

PRASAD, M.B.N.V.; RAVISHNKAS, H.R.A. A note on polyembryonic studies in different cultivars and selections of Rangpur lime. Haryana Journal of Horticultural Sciences, New Delhi, v.11, n.3-4, p.213-214, 1982.

SAIPARI, E.; GOSWAM, A.M.; DADLANI, M. Effect of seed drying on germination behaviour in citrus. Scientia Horticulturae, Amstardam, v.73, n.2-3, p.185-190, 1998.

SILVA, L.F.C.; CARVALHO, S.A. Germinação da semente de porta-enxertos de citros em função da presença do tegumento e sua orientação no substrato. Laranja, Cordeirópolis, v.28, n.1-2, p.47-60, 2007.

SIQUEIRA, D.L.; VASCONCELLOS, J.F.F.; DIAS, D.C.F.S.; PEREIRA, W.E. Germinação de sementes de porta-enxertos de citros após o armazenamento em ambiente refrigerado. Revista Brasileira de Fruticultura, Jaboticabal, v.24, n.2, p.317-322, 2002.
SOARES FILHO, W. dos S.; DIAMANTINO, M.S.A.S.; MOITINHO, E.D.B.; CUNHA SOBRINHO, A.P. da; PASSOS, O.S. 'Tropical': uma nova seleção de tangerina 'Sunki'. Revista Brasileira de Fruticultura, Jaboticabal, v.24, n.1, p.127-132. 2002.

SOARES FILHO, W. dos S.; MORAIS, L.S.; CUNHA SOBRINHO, A.P. da; DIAMANTINO, M.S.A.S. ; PASSOS, O.S. Santa Cruz: uma nova seleção de limão Cravo. Revista Brasileira de Fruticultura, Jaboticabal, v. 21, n. 2, p. 222-225, 1999.

STRUIVING, T.B.; SANTOS, D.; MACHADO, D.L.M.; SIQUEIRA, D.L.; LUCENA, C.C.; MATARAZZO, P.H.M. Qualidade de sementes de porta-enxertos de citros durante o armazenamento In: CONGRESSOBRASILEIRODEFRUTICULTURA, 20., 2008. Vitória. Anais... Vitória: Sociedade Brasileira de Fruticultura, 2008. CD-ROM.

ZONTA, E.P.; MACHADO, A.A.SANEST - sistema de análise estatística para microcomputadores. Pelotas: UFPEL, 1984. 75p.

ZUCARELI, V.; BONJOVANF, R.; CAVARIANI, C.; NACAGAWA, J. Tolerância a dessecação e influência do tegumento na germinação de sementes de citrumelo Swingle. Revista Brasileira de Fruticultura, Jaboticabal, v.31, n1, p.291-295, 2009. 